STUDIA ROSSICA POSNANIENSIA, vol. XLII: 2017, pp. 149-155. ISSN 0081-6884.

Adam Mickiewicz University Press, Poznań

\title{
СЛОВАРНЫЕ ГЛАГОЛЬНЫЕ ОМОГРАФЫ В РУССКОМ ЯЗЫКЕ
}

\author{
RUSSIAN VERBS HOMOGRAPHIC IN THEIR INFINITIVE FORMS
}

\author{
JERZY KALISZAN
}

\begin{abstract}
The author analyzes the homographic potency of Russian verbs stressed differently in their infinitive forms, such as úkamı - uкámı, mpýcumь - mpycúmı, сре́зать - среза́mь etc. In contemporary Russian there are about 350 of these pairs. They are able to create over 3,200 pairs of predicative homographs and almost 27,000 pairs of attributive (participial) homographs.
\end{abstract}

Jerzy Kaliszan, Uniwersytet im. Adama Mickiewicza w Poznaniu, Poznań - Polska, kaliszan@amu.edu.pl

Русский язык известен огромным числом омографов - одинаковых по написанию словесных единиц, различающихся по произношению и значению. Речь идет главным образом об акцентных омографах, т. е. омографах, дифференцированных по месту ударения, типа мука - мука, икать - икать, атласный (к атлас 'сборник географических карт') - атласный (к атлас 'ткань'), косищь (к косить I 'сжинать косой') - косищь (к косить II 'кривить, искривлять'), стоят (к сточть) - стоят (к стоять), руки (род. ед.) - руки (им. и вин. мн.), боров (им. ед.) 'кабан' - боров (род. мн. к бор 'лес'), потом (твор. ед. к пот) - потом (нареч.), пропасть (сущ.) - пропасть (глаг.), гостя (род. и вин. ед. к гость) - гостя (дееприч. к гостить) ${ }^{1}$. С некоторой долей условности к акцентным омографам могут быть отнесены и разноударные „ё-омографы” - слова или формы одного слова, идентичное написание которых связано с непростановкой в одном из них точек над $e$ : боек (кратк. ф. прил. бойкий) - боек (= боёк 'ударная часть механизма, инструмента'), берег - берег (= берёг), ведро (= вёдро 'ясная погода') - ведро 'емкость', пчелы (= пчёлы) - пчелы, жены (=жёны) - жены, села (= сёла) - села и т. п. Акцентным омографам можно противопоставить другие, мало распространенные, типы омографов - акцентно-фонематические: тире [r'] (предл. ед. к тир) - тире [r] 'пунктуационный знак', карате $[\mathrm{t}]$ 'искусство борьбы' - карате [t'] (предл. ед. к карат 'единица

1 Здесь и далее ударные гласные пропечатаны жирным шрифтом. 
массы в ювелирном деле') и фонематические: конецно [š] 'вводное слово' - конечно [с̌'] (кратк. ф. к конечный), теста [t'] (род. ед. к тесто) - meсma [t] (род. ед. к тест), аг्a $[\mathrm{g}]$ 'придворный титул в султанской Турции' - ага $[\mathrm{h}]$ (част. и межд.).

Акцентные омографы, как показывают приведенные примеры, могут быть словарными, т. е. имеющими идентичные по написанию, но различные по произношению и значению номинативные (назывные, исходные, начальные, заголовочные, леммные) формы, например мука - мука, икать - икать, атласныи - атласный, пропасть - проnасть, и несловарными, т. е. фонетически различными, но графически тождественными формами лексем, не омографичных в своих исходных формах, например косишь - косишь, стоят - стоят, боров - боров, потом - потом. Кроме словарных и несловарных акцентных омографов следует еще выделить омографы, представляющие собой формы одной и той же лексемы, вроде указанных выше руки - руки или водите (индикатив) - водите (императив), синее (платье) - синее (компаратив к синиі) и т. п. Этого типа омографы обычно называются грамматическими른 или парадигматическими ${ }^{3}$.

В настоящей статье речь пойдет о словарных омографах в сфере только одной части речи - глагола. Этот вид глагольных омографов, да и не только глагольных, не был до сих пор объектом отдельного анализа. Мало того, в литературе можно даже встретиться с положением, что словарные омографы вообще играют маргинальную роль в системе русской омографики ${ }^{4}$. Между тем, как показывают данные проведенных нами эмпирических исследований, они как раз формируют ц е н т р омографических явлений русского языка, и именно поэтому заслуживают самого пристального внимания.

Целью данной статьи является попытка характеристики омографических рядов, генерируемых парами глагольных лексем, имеющих разноакцентные заглавные формы. В задачу статьи входит, в частности, установление омографического потенциала этого рода пар лексем в зависимости от аспектуального признака компонентов отдельных пар.

2 А. И. М е л ь н и к о в а, К вопросу о русских омографах, „Русский язык в школе” 1974, № 4; ее же, Пути возникновения и развития омографии в русском языке, „Русский язык в школе" 1988, № 4 .

${ }^{3}$ Н. П. К о ле е н и к о в, Система словесных омонимов в русском языке, [в:] ХІІ научная сессия филологического факультета. План работы и тезисы докладов, Издательство Тбилисского университета, Тбилиси 1968, с. 27-29.

${ }_{4}^{4}$ См., напр.: А. В. В е н ц о в, Е. В. Г р у д е в а, В. Б. К а с е в и ч и др., Словарь омографов русского языка, Филологический факультет СПбГУ, Санкт-Петербург 2004, c. 12. 
В соответствии с данными составленного нами словаря разноударных лексем ${ }^{5}$, опирающегося на комплектный материал новейших словарей различных типов - толковых, орфографических, орфоэпических, грамматических, словарей омонимов, омографов и некоторых других лексикографических источников 6 , в современном русском языке налицо около 350 пар глаголов, имеющих омографичные исходные (инфинитивные) формы. Это такие глагольные пары, как багрить 'вытаскивать багром' - багрить 'обагрять, окрашивать в багряный цвет', вздљоить 'удвоить, перестроить ряд в строю в два ряда' - вздвоить 'вторично вспахать (почву, поле)', добегать 'кончить бегать' - добегать 'достигать какого-л. места бегом', утопать 'утоптать' - утопать 'тонуть' и т. п.

Как видно из примеров, глаголы, омографичные в инфинитивных формах, могут быть либо одинаковыми (багрить - багрить, вздвоить - вздвоить), либо различными (добегать - добегать, утопать - утоnать) по аспектуальному значению. В первом случае имеем дело с чисто лексическим омографами, так как компоненты бинарного омографического ряда различаются только лексическим значением; во втором случае компоненты инфинитивных пар представляют собой лексико-грамматические омографы, так как они отличны друг от друга и по лексической, и по грамматической (аспектуальной) семантике 7 .

Лексические (равноаспектные) глагольные омографы целесообразно делить на полные (абсолютные) и неполные (частичные). Полные глагольные омографы - слова, омографичные друг другу во всех своих параллельных (одинаковых по грамматическому значению) формах: в инфинитивной форме, в формах спряжения и формах причастий и деепричастий (если последние считать частью глагольной парадигмы). Так, к полным омографам относятся, например, пары икать 'произносить звук [и] в безударных слогах на месте написания букв „, $\mathrm{e}^{\prime}$

${ }^{5} \mathrm{~J} . \mathrm{K}$ a $\mathrm{l}$ i s z a n, Словарь омографов русского языка, Wydawnictwo Naukowe UAM, Poznań 2015.

${ }^{6}$ См. там же, с. 15-16.

7 Деление омографов (не только глагольных) на лексические и лексико-грамматические является общим местом современных классификаций русской омографии и находит выражение между прочим в следующих работах: О. Н. Е м е л ь я н о в а, Омонимия и смежные явления, [в:] Стилистический энциклопедический словарь русского языка, ред. М. Н. Кожина, Флинта: Наука, Москва 2003, с. 263-267; А. И. М е л ь н и к о в а, К вопросу о русских омографах, указ. соч.; ее же, Пути возникновения..., указ. соч.; М. Г. П е т р е н к о, Явление омографии в современном русском языке. Автореф. дисс. ...канд. филол. наук, Одесский государственный университет им. И. И. Мечникова, Одесса 1987, с. 3; М. И. Ф о м и н а, Современный русский язык. Лексикология, Высшая школа, Москва 1978, с. 62-63. 
и „я"' - икать “непроизвольно издавать гортанью короткие отрывистые звуки, вызываемые судорожным сокращением диафрагмы'; мекать 'говорить нечленораздельно' - мекать 'думать, предполагать'; миловать 'прощать вину' - миловать 'изъявлять любовь'; пикировать 'снизиться, снижаться на большой скорости в почти вертикальном положении (о самолете, птице)' - пикировать 'произвести, производить пересадку всходов растений'. Приведем некоторые пары грамматически равнозначных спрягаемых и атрибутивных (причастных и деепричастных) форм этих глаголов: икаю - икаю, икаешь - икаешъ..., икал - икал, икала - икала, икало - икало, икали - икали, икай-икай, икайте - икайте, икая - икая, икающий - икающий, икающего - икающего..., икающее - икающее..., икающая - икающая, икающей - икающей.., икающие - икающие, икающих - икающих..., икавший - икавший, икавшего - икавшего..., икавшее - икавшее..., икавшая - икавшая, икавшеи - икавшей..., икавшие - икавщие, икавших - икавших... В свою очередь, неполными омографами следует признать такие, например, глаголы, как вздвоить 'удвоить, перестроить ряд в строю в два ряда' - вздвоить 'вторично вспахать (почву, поле)', отворожить 'обратить в творог (молоко, сливки); створожить' - отворожить 'ворожбой избавить от опасного, неприятного', парить 'подвергать действию пара' - парить 'лететь, держась в воздухе на неподвижно распростертых крыльях', трусить 'бояться' - трусить 'тряся, встряхивая, ссыпать вместе', - по той причине, что при всех прочих омографических формах они имеют неомографичные формы повелительного наклонения: вздвой(me) - вздвои(те), отворожь(те) - отворожи (те), парь(те) - пари (те), трусь(те) - тру$\boldsymbol{c u}(m e)$. По природе вещей неполными являются и те словарные омографы, которые отличаются друг от друга числом наличных парадигматических форм, т. е. имеющие неравнообъемные, асимметричные парадигмы. Например, омографы нашивать (многократн. к носить) и нашивать (несов. к нашить) не могут быть абсолютными ввиду отсутствия у первого форм настоящего времени. Необходимо указать, что неполные омографы составляют ядерную часть словарных равноаспектных омографов, полные же омографы встречаются намного реже и, по нашим данным, составляют не более чем пятую часть равноаспектных омографических оппозиций.

Неполными омографами, естественно, являются все разноаспектные омографы - с одной стороны, глаголы типа добегать 'кончить бегать' - добегать (несов. к добежать), искушать 'отведать, покушать' - искушать (несов. к искусить), набухать 'набросать, налить и т. п. слишком много' - набухать 'отекать, пухнуть', недосыпать 'всыпать, насыпать недостаточно, меньше, чем следует, требуется' - недосып ать 'спать меньше, чем это необходимо', отпадать 'перестать, кончить па- 
дать (о снеге, дожде, листьях)' - отпадать (сов. к отпасть), свариться 'браниться, ссориться' - сbариться 'стать готовым в результате варки, кипячения', утопать - утопать, а с другой стороны, глаголы, образующие видовую пару: окликать - окликать, присыпать - присыпать, отмерять - отмерять, зарезать - зарезать и т. п. Несмотря, однако, на различия между системами форм глаголов, образующих отдельные пары, эти глаголы, тем не менее, способны давать целые серии омографических оппозиций. Ср.: добегаю - добегаю, добегаещь - добегаешь, добегает - добегает, добегаем - добегаем, добегаете - добегаете, добегают - добегают; добегай - добегай, добегайте - добегайте; добегал - добегал, добегала - добегала, добегало - добегало, добегали - добегали; добегавиий - добегавиий.., добегавшая - добегавшая..., добегавмее - добегавмее..., добегавшие - добегавшие...; окликал - окликал, окликала - окликала, окликало - окликало, окликали - окликали; окликавший - окликавший.., окликавшая - окликавшая..., отмеряю - отмеряю, отмеряешь - отмеряешь, отмеряет - отмеряет, отмеряем - отмеряем, отмеряете - отмеряете, отмеряют - отмеряют; отмеряй - отмеряй, отмеряйте - отмеряйте; отмерял - отмерял, отмеряла - отмеряла, отмеряло - отмеряло, отмеряли - отмеряли; отмерявший - отмерявший..., отмерявшая - отмерявиая..., отмерявиее - отмерявиее.., отмерявшие - отмерявшие...; ср. также пары причастных омографов типа добегавшим (дат. ед., м. / с. р.) - добегавшим (дат. мн.), добегавщей (род. / дат. / твор. / предл. ед., ж. р.) - добегавшей (род. / дат. / твор. / предл. ед., ж. р.) и т. п.

Словарные глагольные омографы могут быть как родственными (однокоренными), так и неродственными (разнокоренными) словами. Из родственных слов состоят такие омографические оппозиции, как вздвоить 'удвоить, перестроить ряд в строю в два ряда' - вздвоить 'вторично вспахать (почву, поле)', выбегать 'достичь, добиться беганьем по многим местам, инстанциям' - выбегать (несов. к выбежать), заползать 'начать ползать' - заползать 'забираться, пробираться, проникать ползком'. К неродственным, в свою очередь, относятся, между прочим, омографы типа воронить 'ротозейничать' - воронить 'чернить', замыкаться 'начать мыкаться, бестолково, беспорядочно двигаться' - замыкаться 'запираться, закрываться', утопать 'топая, примять, утоптать' - утопать 'тонуть'. Между парами однокоренных и разнокоренных глагольных омографов имеется заметная количественная диспропорция в пользу первых: они составляют $60 \%$ всех пар словарных глагольных омографов.

Нет сомнения, что количественный перевес однокоренных глагольных омографических оппозиций над ранокоренными проистекает из того, что значительное число омографических оппозитов пред- 
ставляют собой соотношение мотивирующего и мотивированного слов. Так, в нашем материале имеется около 100 пар соотносительных по виду глаголов с корнями -сыn-, -рез-, -клик-, -мер- типа засыпать - засыnать, досыпать - досыпать, отсыпать - отсыпать, высыпать - высыпать, высыпаться - высыпаться, засыпаться - засыпаться; разрезать - разрезать, вырезать - вырезать, изрезать - изрезать, нарезать - нарезать, надрезать - надрезать, срезать - срезать, надрезаться - надрезаться, прорезаться - прорезаться; выкликать - выкликать, закликать 'зазвать' - закликать 'зазывать', накликать - накликать, окликать 'окликнуть' - окликать, прикликать - прикликать; вымерять - вымерять, домерять - домерять, обмерять - обмерять, промерять - промерять, размерять - размерять. В таких видовых парах имперфективный член является дериватом перфективного члена: засыпать $\rightarrow$ засыпать, разрезать $\rightarrow$ разрезать, прикликать $\rightarrow$ прикликать, вымерять $\rightarrow$ вымерять 8 .

Вообще можно сказать, что словообразование является основным и едва ли не единственным источником образования глагольных омографов словарного типа. Это в равной мере касается как однокоренных, так и разнокоренных омографов. Так, словообразовательный фактор лежит в основе 315 пар словарных омографов из 350 отмеченных. Кроме указанных корреляций типа засыпать - засыпать, разрезать - разрезать, прикликать - прикликать, вымерять - вымерять, актуальную связь со словообразованием обнаруживают такие, например, пары, как выкупать (от купать) - выкупать (несов. от выкупить), вылетать 'израсходовать горючее во время полета (о самолете)' - вылетать (несов. от вылететь), задвигать 'начать двигать' - задвигать (несов. от задвинуть), сбегаться (от бегать) 'научиться бегать в паре, тройке, вместе с другими в упряжке (о лошадях)' - сбегаться (несов. от сбежаться), рассорить (от ссора) 'вызвать ссору, поссорить' - рассорить (от сорить) 'роняя, рассыпать'. Немалую их часть - 125 пар - составляют корреляции отраженных омографов, т. е. омографов, копирующих омографичность мотивирующих слов, напр.: допарить (от парить) - допарить (от парить), забронировать (от бронировать) - забронировать (от бронировать), потупить (от тупить) - потупить (от тупить), тупиться (от тупить) - тупиться (от тупить), нашиваться (от нашивать) - нашиваться (от нашивать).

Охарактеризованная в данной статье разновидность глагольной омографии - омография слов, имеющих одинаковые по написанию,

8 Вслед за академической Русской грамматикой (ср.: Русская грамматика, ред. Н. Ю. Шведова, т. І, Наука, Москва 1980, с. 584) члены видовой пары мы считаем двумя автономными лексемами, в связи с чем корреляции типа засыпать - засыпать, разрезать - разрезать и т. п. трактуются нами как словообразовательные, а не словоизменительные. 
но различные по значению и произношению словарные (инфинитивные) формы - составляет становой хребет современной русской глагольной омографии. Эта разновидность, если иметь в виду только инфинитивные и спрягаемые (предикативные) формы, насчитывает, по нашим данным, свыше 3200 оппозиций. Если же добавить к ним и оппозиции атрибутивных (причастных и деепричастных) форм, то общее число омографических корреляций, инициируемых рассматриваемыми 350 инфинитивными парами, достигнет уровня 30 тысяч. Столь огромное число омографических корреляций, имплицируемых парами глагольных лексем с разноударными словарными формами, обеспечивает глаголу как части речи абсолютно доминирующее место на омографической карте современного русского языка. Для сравнения укажем, что в сфере русских существительных и прилагательных нами было обнаружено соответственно 200 и 70 пар глаголов с разноударными назывными формами, способных генерировать, по данным нашей картотеки, соответственно около 2700 и 4800 омографических рядов.

\section{Библиография}

В е н ц о в А. В., Г р у д е в а Е. В., К а с е в и ч В. Б. и др., Словарь омографов русского языка, Филологический факультет СПбГУ, Санкт-Петербург 2004, с. 12.

Е м е л в я н о в а О. Н., Омонимия и смежные явления, [в:] Стилистический энциклопедический словарь русского языка, ред. М. Н. Кожина, Флинта: Наука, Москва 2003.

K a 1 i s z a n J., Словарь омографов русского языка, Wydawnictwo Naukowe UAM, Poznań 2015.

К о л е с н и к о в Н. П., Система словесных омонимов в русском языке, [в:] ХІІ научная сессия филологического факультета. План работы и тезисы докладов, Издательство Тбилисского университета, Тбилиси 1968, с. 27-29.

М е льн и к о в а А. И., К вопросу о русских омографах , Русский язык в школе” 1974, № 4.

М е ль н и к о в а А. И., Пути возникновения и развития омографии в русском языке, „Русский язык в школе” 1988, № 4.

П е т р е н к о М. Г., Явление омографии в современном русском языке. Автореф. дисс. ...канд. филол. наук, Одесский государственный университет им. И. И. Мечникова, Одесса 1987.

Русская грамматика, ред. Н. Ю. Шведова, т. І, Наука, Москва 1980.

Ф о м и н а М. И., Современный русский язык. Лексикология, Высшая школа, Москва 1978, c. 62-63. 
